\title{
The Concept of End-to-End Risk Management of Commercial Business Organizations Under Conditions of Digitalization of Russian Economy
}

\author{
Dmitry Mikhailovsky \\ $\mathrm{CCO}$ \\ Alliance GROUP CJSC \\ Saint Petersburg, Russia \\ d.a.mikhailovsky@yandex.ru
}

\author{
Vladimir Kunin \\ St. Petersburg University of Management Technologies and \\ Economics \\ Saint Petersburg, Russia \\ v.kunin50@yandex.ru
}

\begin{abstract}
In the light of the development of modern digital technologies, the development and integration of new business process management systems for commercial business organizations is a very serious problem. Methods for reducing the negative result by promptly localizing and absorbing the risk effect on the business processes of trading organization have been developed and presented, methods for implementing an automated, decentralized risk management system in the organization's strategic management system have been found. Task management and control mechanism within RMS of business organization has been structured with details of main principles of the risk management system. Methods for integrating management system models CRM, ERM, SCM, PLM in the RMS format with the use of KPI elements have been defined. The concept of end-to-end risk management proposes the use of a flexible project management system Agiale, which is an effective technique for organizing work under uncertainty. The scientific findings of this article reveal and formalize the tools and criteria for end-to-end risk management of business organizations. With regard to commercial business, the article content provides managers with necessary tools for automating the risk management process using modern digital technologies.
\end{abstract}

Keywords: commercial entrepreneurship, risk management, end-to-end risk management

\section{INTRODUCTION}

The development of modern digital technologies changes old business models, providing an entrepreneur with conceptually new tools that allow to optimize business processes, customize offers and advertising, create new products, new markets within the growing demand for digital innovations.

The economic literature has many studies conducted on issues of risk management, among which, the studies of Algin A. P., Balabanov I. T., Burgonov O.V., Buyanov V.P., Golubev A.I., Grabovoy P.G., Kantilyon, M. Lapusta, J. Mill, F. Knight, D. Ricardo, Telman, Heinrich von Thünen, etc., are particularly noteworthy. Most authors of publications on risk management agree that the purpose of RSM, first of all, is to mitigate adverse impacts of risks, reduce losses, etc. It should be noted that almost all authors agree that the RSM should not exist as a separate tool in management and should be integrated into the overall management system of the company.[1,2]

However, it must be brought to the attention that the development of modern digital technologies provides an opportunity to re-engineer the risk management process within the new paradigm that aimed at the decentralization of business processes. However, digital transformation of the economy, along with tremendous opportunities, has also created new significant risks that have not yet been understood and assessed, and requires additional scientific research. In addition, it should be noted that the vast majority of scientific research on risk management focuses on one particular stage of RSM lifecycle.[3] At the same time, RSM should ensure end-to-end effective risk management from pre-realization phase to after-effect stage, when the risk has already been realized, but negative consequences of its realization still have a negative effect on a business organization.[4,5]

This article presents the concept of end-to-end business risk management, which combines all phases of risk impact on business processes of commercial business organizations, and which lays the foundation for creation and integration of an automated, decentralized RSM.

\section{MEthodology AND THEORY}

The rapid scientific and technological progress development form certain trends in the economy, politics, society, which change the way we lived before. Due to the high degree of integration, trends formed at the global level are rapidly spreading at the national level, while creating modern risk factors that form a new business risks landscape. Thus, different types of risks generated at the global level have 
calculated and a compensatory risk management method is determined. In case of exposure to long-term risks, the damage is calculated for a certain time period.

When formalizing the management procedure at each of these phases, we will follow the following basic principles.

- The principle of permanence, according to which endto-end risk management should be a continuous process characterized by the consistent, continuous use of methods and tools of RSM in the economic activity of a business entity, taking into account the experience in previous use at each phase of the risks.

- The principle of feedback, according to which the methods and tools of risk management should be adjusted based on the effectiveness analysis and assessment of the methods and tools used.

- The principle of reciprocal effects of risks, according to which risk management should take into account the reciprocal effect of risks and precursors are identified in time.

- The principle of integration, according to which the RSM should be integrated into the overall management system of the company. [8]

- The principle of effectiveness. Risk management creates and protects the Company value. The purpose of RSM is to ensure sustainable competitive business development by reducing unexpected costs, protecting the company image that have positive impact on customer loyalty and sales volume. All risk management measures should be economically sound and should not exceed the alleged damage cost from the activation of risks.

- The principle of responsibility. Responsibility for risks means that there is a comprehensive, fully established and accepted responsibility for activation and negative consequences of risks, both on the part of management structures and individual employees.[9]

- The principle of completeness of information used. The risk management process takes into account all available information, including Internet data.[10,11]

The concept of end-to-end risk management at all stages of the management process proposes the use of a flexible project management system Agiale, which is an effective technique

TABLE I.

END-TO-END RISK MANAGEMENT MECHANISMS

\begin{tabular}{|c|c|c|c|}
\hline Phase & Management goal & Management objective & Criteria \\
\hline 1.Pre-risk phase & $\begin{array}{l}\text { Prevent an efficiency reduction of company's } \\
\text { business operations and competitiveness induced } \\
\text { by possible activation of risks }\end{array}$ & $\begin{array}{l}\text { 1. Risk activation } \\
\text { prevention } \\
\text { 2. Reducing the negative } \\
\text { consequences of risk }\end{array}$ & $\begin{array}{l}\text { Minimize performance indicator and } \\
\text { competitiveness variation of business operations } \\
\text { while ensuring the required values of indicators } \\
\text { specified. }\end{array}$ \\
\hline $\begin{array}{l}\text { 2.Risk realization } \\
\text { phase }\end{array}$ & $\begin{array}{l}\text { Minimize an efficiency reduction of company's } \\
\text { business operations and competitiveness induced } \\
\text { by realized risk }\end{array}$ & $\begin{array}{l}\text { 1. Reducing the negative } \\
\text { effects of risk }\end{array}$ & $\begin{array}{l}\text { Performance and competitiveness indicators growth } \\
\text { as a result of reactive risk management measures }\end{array}$ \\
\hline $\begin{array}{l}\text { 3. Consequences } \\
\text { phase }\end{array}$ & $\begin{array}{l}\text { Get the company's efficiency of business operations } \\
\text { and competitiveness back on track after risk is } \\
\text { realized }\end{array}$ & $\begin{array}{l}\text { 1. Mitigating the adverse } \\
\text { impacts of realized risk }\end{array}$ & $\begin{array}{l}\text { Recovering performance and competitiveness } \\
\text { indicators up to values typical for the pre-risk phase }\end{array}$ \\
\hline
\end{tabular}


TABLE II. END-TO-END RISK MANAGEMENT TOOLS

\begin{tabular}{|c|c|c|}
\hline Phase & Management tools group & Management tools \\
\hline \multirow[t]{8}{*}{$\begin{array}{c}\text { Pre-risk } \\
\text { phase }\end{array}$} & Risk aversion & $\begin{array}{l}\text { 1. Regulations for decision-making on refusal of high-risk activities. } \\
\text { 2. Safety regulations } \\
\text { 3. Risk assessment methods } \\
\text { 5. Regulatory agency standards }\end{array}$ \\
\hline & Offsetting risk & $\begin{array}{l}\text { 1. Pricing methods that offset the impact of risk } \\
\text { 2. Product line liquidity indicators } \\
\text { 3. Market price indicators } \\
\text { 4. Legal methods }\end{array}$ \\
\hline & Risk distribution & 1. Regulations that govern business process management through outsourcing. \\
\hline & Risk diversification & $\begin{array}{l}\text { 1. Regulations that define proportions between suppliers } \\
\text { 4. Regulations that structure the proportions of brands as part of the product range. } \\
\text { 5. Capital allocation regulations between banks and different projects. }\end{array}$ \\
\hline & Risk localization & $\begin{array}{l}\text { 1. Regulations that limit the scope of delivery through a single channel } \\
\text { 2. Methods and regulations that limit the period and amount of payment delay for wholesale customers }\end{array}$ \\
\hline & External insurance & $\begin{array}{l}\text { 1. Cargo insurance contracts } \\
\text { 2. Property insurance contracts } \\
\text { 3. Employee life and health insurance programs } \\
\text { 4. Regulations that determine the economic feasibility of insurance }\end{array}$ \\
\hline & Self-insurance & $\begin{array}{l}\text { 1. Regulations for creation of reserve funds. } \\
\text { 1. Regulations for creation of current assets reserve stock. }\end{array}$ \\
\hline & Hedging & $\begin{array}{l}\text { 1. Options } \\
\text { 2. Futures contracts } \\
\text { 3. Forward contracts }\end{array}$ \\
\hline \multirow{2}{*}{$\begin{array}{c}\text { Risk } \\
\text { realizati } \\
\text { on phase }\end{array}$} & $\begin{array}{l}\text { Tools for generating financial } \\
\text { resources to compensate the damage }\end{array}$ & $\begin{array}{l}\text { 1. Regulations and methods of compensatory pricing } \\
\text { 2. Legal regulations }\end{array}$ \\
\hline & $\begin{array}{l}\text { Tools for preventing a worsening of } \\
\text { negative consequences of risk } \\
\text { activation }\end{array}$ & $\begin{array}{l}\text { 1. Orders and regulations that form a rapid response to the impact of risk. } \\
\text { 2. Safety regulations } \\
\text { 3. Instruments and orders of regulatory authorities }\end{array}$ \\
\hline \multirow[t]{2}{*}{$\begin{array}{l}\text { Consequ } \\
\text { ences } \\
\text { phase }\end{array}$} & Tools for increasing sales volume & $\begin{array}{l}\text { 1. Advertising campaign and promotions } \\
\text { 2. Methods and indicators of commodity pricing } \\
\text { 3. Methods of offered product customization } \\
\text { 4. Training programs for sales staff } \\
\text { 5. Staff motivation regulations }\end{array}$ \\
\hline & Tools for cutting overall costs & $\begin{array}{l}\text { 1. Business process automation } \\
\text { 2. Business process optimization methods } \\
\text { 3. Program and regulations for automating the organization's infrastructure } \\
\text { 4. Regulations that optimize the retail area of business organization. }\end{array}$ \\
\hline
\end{tabular}

for organizing work under uncertainty.

Table 1 shows the formalization of elements of risk management mechanisms at each phase of their existence proposed by the authors.

Table 2 shows the systematic disclosure of possible endto-end risk management tools of commercial business organizations.
The work is performed iteratively - in short cycles (one two weeks), goals and objectives are set at the beginning of each cycle, at the end - the work undertaken is summarized.[12]

To achieve strategic goals at each phase of risk management, strategic objectives are set for the business organization as a whole. Each department is VECTOR-tasked that define the principle directions of RSM in the area of

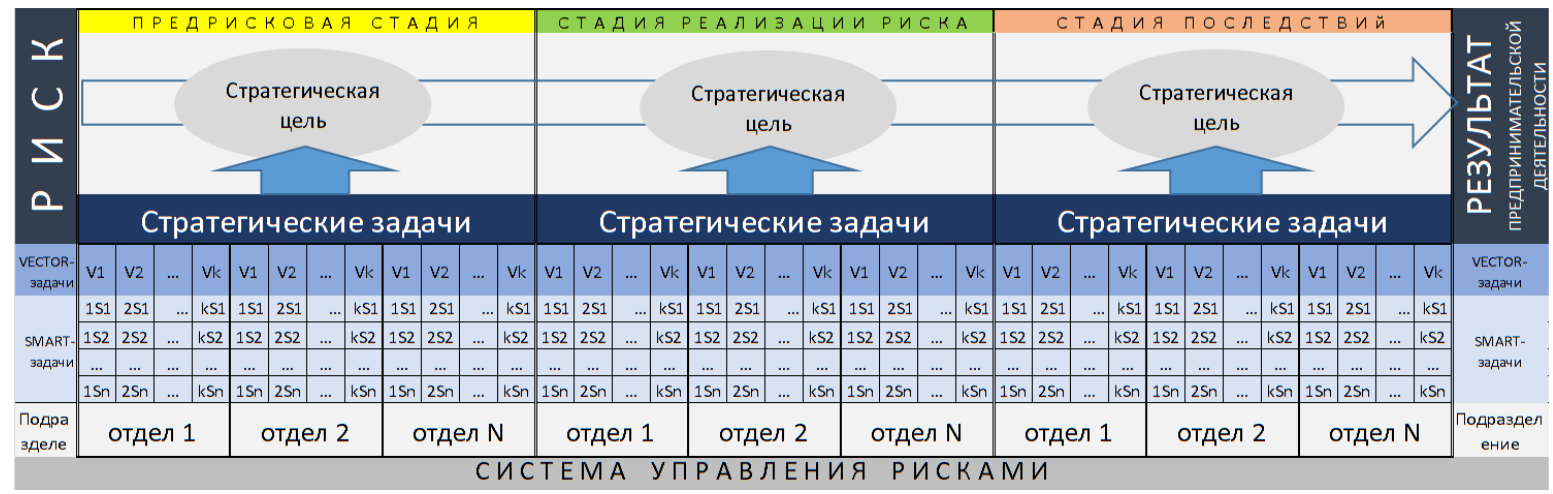

Fig. 1. Scheme of end-to-end risk management of the business structure 
TABLE III. END-TO-END RISK MANAGEMENT TOOLS

\begin{tabular}{|c|c|c|c|c|c|}
\hline department & \multicolumn{4}{|c|}{ SMART - tasks } & \multirow[t]{2}{*}{ VECTOR- tasks } \\
\hline & & & & & \\
\hline \multirow{2}{*}{ financial } & S1 & S2 & & $\mathrm{Sn}$ & Provide a forecast for changes in financial position \\
\hline & S1 & S2 & & $\mathrm{Sn}$ & Introduction of self-insurance programs, reserve creation \\
\hline legal & S1 & S2 & . & $\mathrm{Sn}$ & Ensure that programs being introduced comply with the legislation \\
\hline purchasing & S1 & S2 & $\ldots$ & $\mathrm{Sn}$ & Develop information bases for alternative products. \\
\hline \multirow{2}{*}{ marketing } & S1 & $\mathrm{S} 2$ & . & $\mathrm{Sn}$ & Provide a demand shift forecast \\
\hline & S1 & S2 & $\ldots$ & $\mathrm{Sn}$ & Analyze the alternative products and brands market \\
\hline & & & & & RIsk realizatIon phase \\
\hline \multirow{2}{*}{ financial } & S1 & S2 & $\ldots$ & $\mathrm{Sn}$ & Organize the self-insurance programs implementation \\
\hline & S1 & S2 & $\ldots$ & $\mathrm{Sn}$ & Develop damages compensation programs \\
\hline legal & S1 & S2 & $\ldots$ & $\mathrm{Sn}$ & Provide legal support during the implementation of risk management programs \\
\hline purchasing & S1 & S2 & $\ldots$ & $\mathrm{Sn}$ & Organize the supply of alternative products \\
\hline \multirow{2}{*}{ marketing } & S1 & S2 & $\ldots$ & $\mathrm{Sn}$ & Determine the extent of demand shift \\
\hline & S1 & S2 & $\ldots$ & $\mathrm{Sn}$ & Make a sales forecast of alternative products \\
\hline sales & S1 & S2 & $\ldots$ & $\mathrm{Sn}$ & Develop and introduce new product sales method \\
\hline security & S1 & S2 & $\ldots$ & $\mathrm{Sn}$ & Provide a reliability report of new suppliers and routes \\
\hline logistics & S1 & S2 & $\ldots$ & $\mathrm{Sn}$ & Develop new supply routes \\
\hline warehouse & S1 & S2 & $\ldots$ & Sn & Ensure that the new product is stored in accordance with the storage rules \\
\hline \multicolumn{6}{|r|}{ Consequences phase } \\
\hline financial & S1 & S2 & . & $\mathrm{Sn}$ & Introduce loss compensation programs \\
\hline marketing & S1 & S2 & $\ldots$ & Sn & Implement a demand stimulation program for new products \\
\hline purchasing & S1 & S2 & . & $\mathrm{Sn}$ & Ensure discounts, payment delay \\
\hline advertising & S1 & $\mathrm{S} 2$ & . . & $\mathrm{Sn}$ & Develop and launch an advertising campaign with new products \\
\hline
\end{tabular}

responsibility of an individual division. VECTOR tasks, in turn, are divided into SMART tasks that have closer and more specific goals.[13] SMART tasks meet the following criteria: concreteness, measurability, achievability, relevance, time constraints. In this case, the planned deadline for one SMART task should not exceed the iteration time, otherwise the task must be decomposed. Figure 1 presents the concept of end-toend risk management in relation to commercial business organizations. In order to assess how effectively a certain division manages private risk, based on specification of SMART tasks parameters, it is proposed to use different KPI systems that allow to effectively assess the extent to which the goal has been achieved, both individual employees and divisions of the business organization.[14]

The concept for commercial entrepreneurship can be automated by developing a separate software based on the use of models of management systems CRM/ERM/SCM/PLM. It will be integrated into existing automated business process management systems through API technology. Automation will be as a cloud product, which ensures that process management is prompt and makes management entities less location dependent. [15]

Based on the studies conducted, the authors have structured in Table 1 elements that reflect the goal of the RSM, from which the objectives and criteria of the risk management system are formed. The list of used management tools presented in Table 2 is grouped according to the objectives performed within the RSM. Each group is a set of tools ensuring that objectives for the risk impact reduction at each phase of its existence are fulfilled. Figure 1 shows the impact of risk on business results. Depending on the risk phase, the RSM has a specific strategic goal whose achievement is ensured by the implementation of strategic objectives, in which each department performs VECTOR tasks, which in turn consist of a number of SMART tasks. Table 3 shows the basic VECTOR tasks performed by the business organization's departments at each phase of risk existence. Each VECTOR task consists of an infinite number of SMART tasks that ultimately ensure that the strategic objectives shown in Figure 1 are completed. The RMS performance evaluation is shown in Figure 2, which shows an example of monitoring the achievement of objectives as illustrated by the pre-risk phase "Increase of customs duties". The SMART task completion phase is assessed using a 100point scale, and the arithmetic mean of these values for each VECTOR task is an indicator of its completion. The arithmetic mean of all VECTOR tasks completed by an individual department indicates that this department has fulfilled the strategic objective. In turn, the arithmetic mean of achievement indicators of strategic goal by all departments involved in the RMS is an indicator of the overall degree to which the strategic goal was achieved at a certain phase of risk existence. Thus, the concept of end-to-end risk management introduced by the authors has effective tools for monitoring and assessing the task completion set for the RSM.

\section{RESUlTS AND DISCUSSION}

Given the rapid development of modern digital technologies and automation of business processes, an important criterion for the effectiveness of risk management is the promptness and systematization of decisions made within the RSM. Integration of modern decentralized management methods in combination with algorithmization of the risk management process increases the effectiveness of end-to-end RSM. 


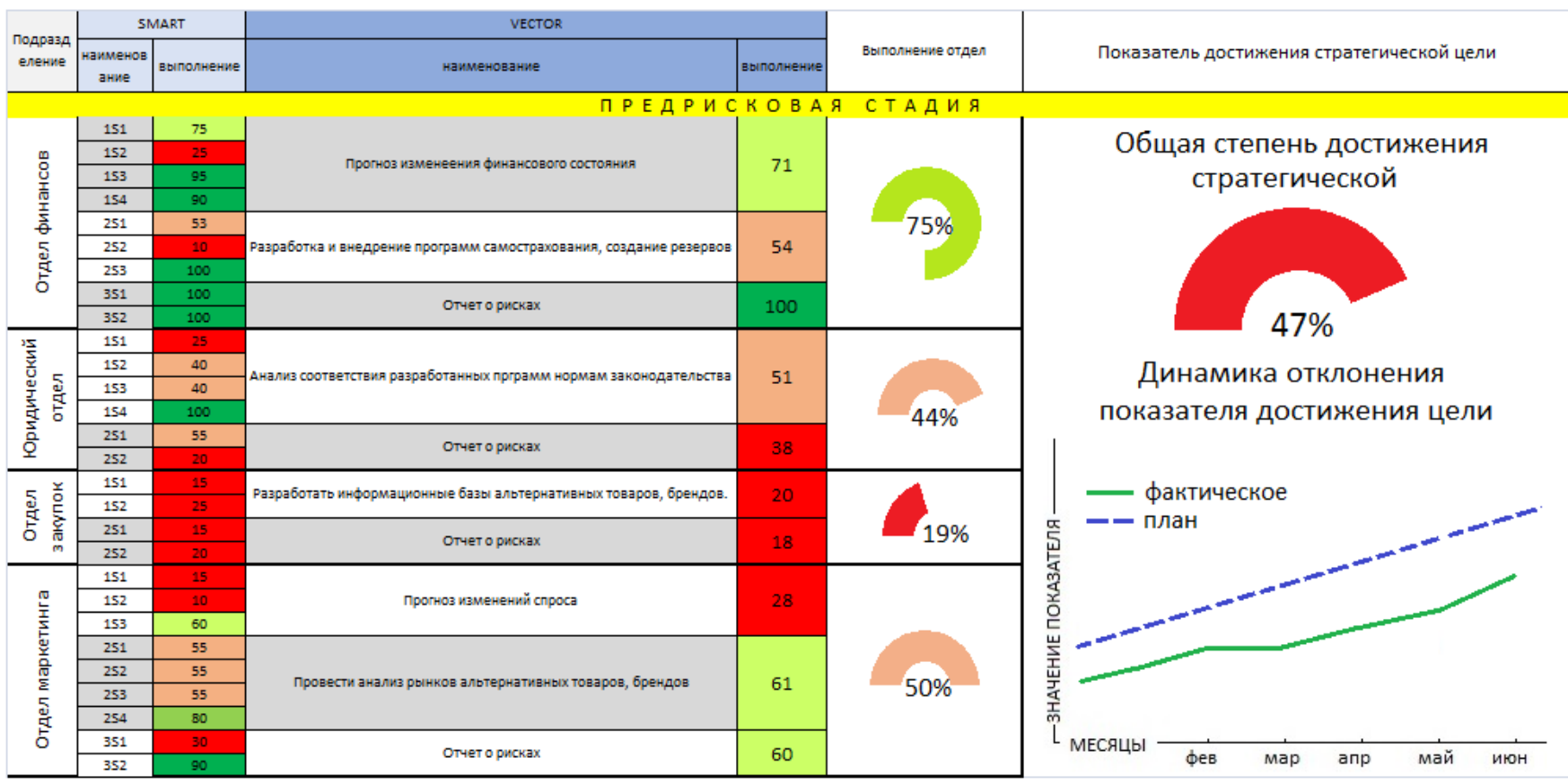

Fig. 2. Example of assessing the RSM effectiveness at the pre-risk phase of risk management "Increase of customs duties"

Methods of performing the tasks of the end-to-end RSM based on Agiale methodology makes it possible to reduce the human factor in the RSM infrastructure, to speed up decisionmaking thanks to decentralization and transparency of the risk management process.

Structuring the tools of end-to-end risk management system in combination with modern management models provides the subjects of RMS with effective tools that allow for prompt impact on risks and its consequences at different phases of risk management of the commercial business organizations.

\section{References}

[1] M. Arntz, T. Gregory, and U. Zierahn, "Revisiting the risk of automation", Economics Letters, vol. 159, pp. 157-160, 2017.

[2] S. Zemtsov, V. Barinova, and R. Semenova, "The Risks of Digitalization and the Adaptation of Regional Labor Markets in Russia”, Foresight and STI Governance, vol. 13, no 2, pp. 84-96, 2019. DOI: $10.17323 / 2500-2597.2019 .2 .84 .96$

[3] A. Chepurenko, "Innovation Entrepreneurship in Transition Economies: Problems and Outlook", Foresight and STI Governance, vol. 11, no 3, pp. 6-9, 2017. DOI: 10.17323/2500-2597.2017.3.6.9.

[4] F. Gault, "User Innovation in the Digital Economy", Foresight and STI Governance, vol. 13, no 3, pp. 6-12, 2019. DOI: 10.17323/25002597.2019.3.6.12.

[5] Chang J.-H., Huynh P. (2016) ASEAN in Transformation: The Future of Jobs at Risk of Automation. Bureau for Employers' Activities Working Paper no. 9. Geneva: ILO.
[6] V.A. Kunin and O.A. Tarutko, "System of indicators of competitiveness of business structures", Problems of modern economy, no. 1 (65), pp. $65-68,2018$

[7] A. Inzelt and L. Csonka, "The Approach of the Business Sector to Responsible Research and Innovation (RRI)", Foresight and STI Governance, vol. 11 , no. 4 , pp. $63-73$, 2017. DOI: $10.17323 / 2500-$ 2597.2017.4.63.73

[8] J. Bessant, "Innovation in the Twenty-First Century", Responsible Innovation, Managing the Responsible Emergence of Science and Innovation in Society, Eds. R. Owen, J. Bessant, M. Heintz. Chichester: John Wiley \& Sons, pp. 1-25, 2013.

[9] J.H. Chang and P. Huynh, ASEAN in transformation: The future of jobs at risk of automation. Geneva: ILO, 2016.

[10] A. Zorgner, "Workplace automation: a threat to employment or a source of entrepreneurial opportunities?", Forsythe, vol. 11, no. 3, pp. 37-48, 2017.

[11] F. Crowley and J. Bourke, "The Influence of the Manager on Firm Innovation in Emerging Economies", International Journal of Innovation Management, vol. 22, no. 3, 2018. DOI: 10.1142/S1363919618500287.

[12] Ruud B.M. Huirne, P.M. Miranda, J. Brian Hardaker, Jock F. Anderson, "Risk and risk management in agriculture: an overview and empirical results", Int. J. Risk Assessment and Management, vol. 1, pp. $25,2000$.

[13] B. Bui, C. Cordery, and Z. Wang, "Risk management in local authorities: An application of Schatzki's social site ontology", The British Accounting Review, 2019. DOI: 10.1016/j.bar.2019.01.001.

[14] Naciye Sekerci and Donald P. Pagach, "Enterprise Risk Management and Corporate Governance", SSRN Electronic Journal, 2019. DOI: $10.2139 /$ ssrn.3366489.

[15] Johanna Sax and Torben Juul Andersen, "Making Risk Management Strategic: Integrating Enterprise Risk Management with Strategic Planning”, European Management Review, 16, 3, pp. 719-740, 2018. 